Osmanlı'dan Cumhuriyet'e Illk Mektepler Talimatnameleri (1915-1929) ${ }^{1}$

Instructions for Primary School from the Ottoman to the Republic (1915-1929)

\title{
Ayşe YANARDAĞ
}

Sivas Cumhuriyet Üniversitesi, Edebiyat Fakültesi, E-posta: yanardag2006@gmail.com orcid.org/0000-0002-5636-3500

Article Info

\begin{tabular}{c|l}
$\begin{array}{c}\text { Article Type } \\
\text { Received }\end{array}$ & $\begin{array}{l}\text { Research \& Theoretical } \\
21.11 .2019 \\
\text { Accepted }\end{array}$ \\
DOI & 10.03 .2020 \\
$\begin{array}{c}\text { Corresponding } \\
\text { Author }\end{array}$ & $\begin{array}{l}\text { Ayşe YANARDAĞ } \\
\text { Yanardağ, A. (2020). Osmanlı'dan Cumhuriyet'e ilk mektepler } \\
\text { talimatnameleri (1915-1929). Turkish History Education Journal, } \\
9(1), \text { ss. 89-108. DOI: 10.17497/tuhed.649570 }\end{array}$
\end{tabular}

\footnotetext{
${ }^{1}$ Bu çalışma 10-12 Ekim 2019 tarihinde Bolu'da VI. Uluslararası Tarih Eğitimi Sempozyumu'nda sözlü bildiri olarak sunulmuştur.
} 
Öz: Osmanlı Devleti'nde klasik dönemde çağdaşları gibi genel halk eğitimini sağlamak üzere belli bir devlet politikası olmamıştır. Bununla birlikte dinsel sebeplerle de olsa Osmanlı medrese, sıbyan gibi eğitim kurumları açılmasına destek vermiştir. Bu eğitim kurumlarından sıbyan mektepleri temel halk eğitimini ilgilendiriyormuş gibi görünse de bunların belli bir programı müfredatı, yönetmeliği, denetimi söz konusu değildi. 19. yüzyılda Osmanlı Devleti'nde gerileme başlayınca devleti kurtarmak için ıslahatlar yapılmaya başlamıştır. Bu bağlamda iyi eğitilmiş bir toplumun devleti kurtaracağı fikriyle eğitim alanında da ıslahatlar yapılmıştır. Eğitim ıslahatları orta ve yüksek eğitimden başlamış, fakat orta ve yüksek eğitimin iyi bir temel eğitim olmadan başarılamayacağı anlaşımıştır. Bu nedenle hemen her yerde kurulan sıbyan mekteplerinde ıslahat yapma ihtiyacı kendini göstermiştir. Tanzimat döneminde başlayan arayış ve uygulamalar, II. Abdülhamit döneminde devam etmiş, II. Meşrutiyet döneminde daha sistematik hale getirilmeye çalışılmıştır. Sıbyan mektepleri bu süreçte yeni modern eğitim veren ibtidai mekteplere dönüştürülmeye çalışılmıştır. 1913'te çıkarılan Tedrîsât-ı İbtidâiyye Kanun-ı Muvakkatının beşinci maddesi gereğince 1915'te Mekatib-i ibtidaiye-i Umumiye Talimatnamesi çıkartılmışır. Talimatname ufak değişikliklerle Cumhuriyet'in ilk yıllarında uygulanmaya devam etmiştir. 1929 yılında yeni bir talimatname çıkarılmıştır. Türk eğitim tarihinde ilköğretimi şekillendiren talimatname hakkındaki değişiklik istekleri ve fikirler Maarif Vekâlet'inin yazışmalarına yansımıştır. Bu yazışmalarda ilköğretim sistemi kurma arayışları açıkça görülmüştür. Çalışmada söz konusu talimatname ve talimatnamenin değiştirilmesine ilişkin arşiv belgeleri kullanıımıştır. Çalışma talimatnamenin çıktığı ve değiştirildiği 1915-1929 yıllarıyla sınırlandırılmıştır. Elde edilen belge ve bilgiler kendi koşullarında sebep sonuç ilişkisi içinde değerlendirilmiş ve süreç açıklanmaya çalışılmıştır.

Anahtar Kelimeler: Illk Mektep, Illk Mektepler Talimatnamesi, Talimatname Tadilatı

\begin{abstract}
In the Ottoman Empire, there was no state policy to provide general public education, such as its contemporaries in the classical period. However, for religious reasons, it supported the establishment of educational institutions such as madrasah and primary level schools (sıbyan mektebi). Although the primary level schools of these educational institutions seemed to concern basic public education, they did not have a specific program, curriculum, regulation and supervision. When the Ottoman Empire began to decline in the 19th century, reforms were made to save the State. In this context, reforms were made in the field of education with the idea that a well-educated society would save the state. Educational reforms started in secondary and higher education, but it was understood that secondary and higher education could not be achieved without a good basic education. For this reason, the need to make improvements has emerged in the primary level schools established almost everywhere. The search and applications that started in Tanzimat period II. During the Constitutional Monarchy period, it was tried to be made more systematic. In this process, primary level schools were tried to be converted into new modern education primary (ibtidai) schools. In 1915, in accordance with the fifth article of the Provisional Primary Education Act issued in 1913, General Instruction for Primary Schools was issued in 1915. The instruction continued to be implemented in the first years of the Republic with minor changes. In 1929, a new instruction was issued. Requests and changes to the regulations on the form of primary education in the history of Turkish education were reflected in the correspondence of the Ministry of Education. In the correspondence, the search for establishing a primary education system was clearly seen. In this study, these instructions and archive documents regarding the amendment of these instructions were examined. Limited to the years 1915-1929, when the work instruction was issued and changed. The obtained documents and information were evaluated in their own conditions, cause and effect relation, and the process was tried to be explained.
\end{abstract}

Keywords: Primary School, Primary Schools Instruction, Instruction Change 


\section{Extended Summary}

\section{Purpose}

The aim of the study is to examine the emergence of the 1915 Mekatib-i ibtidaiye- $i$ Umumiye Instruction, which was the last regulation on primary education in the Ottoman Empire, and the changes made on it. Then, to try to explain the process by making a comparison with the new instruction dated 1929. In this context, the following questions were tried to be answered.

- For what reasons did the 1915 instruction that was examined appear?

- What are the features of the instruction?

- What are the amendments made to the instruction in 1923 and why were they made?

- What are the reasons for making the new instruction made in 1929?

- What are the features of the 1929 instruction?

\section{Method}

The study is primarily a history study, and the instruction itself, the edited prints, archive documents, and various copyrighted works were used. The 1915 instruction was used until 1929 with some changes while passing from the Ottoman to the Republic. For this reason, the study was limited to the years 1915-1929. The process until the preparation of the new instruction has been handled with a historical approach within the cause-effect relationship. The process was tried to be explained by comparing the 1915 and 1929 instructions.

\section{Results and Discussion}

In the 19th century, social and political changes spread from Europe to the whole world, and this was reflected in the understanding of education. Multinational empires collapsed and national states emerged, and education, especially basic education, was among the primary duties of the state with the idea of raising individuals who would own the ideology of the national state. Meanwhile, in the Ottoman State, which was in the process of disintegration, the main aim was to prevent the collapse of the state while seizing education. In this century, a search for a new understanding of education and its applications started in the field of education, and this was called usûl-ı cedîd. Usûl-ı cedîd is the innovations applied in the course materials, books and lesson methods of newly opened schools. With this movement, which was also developed in primary education, schools were called ibtidai. Various arrangements were made in this century for the development of ibtidai schools.

In the Provisional Primary Education Act dated 1913, which was issued in the Constitutional Period, primary education was regulated by a separate law and systematized. According to the relevant article of the Act, the General Instruction for Primary Schools was issued in 1915. The instruction came out during the First World War and reflects the political and social situation of the period. Although the purpose of raising a religious generation is emphasized in the instruction, the emerging idea of Turkism is reflected even though it is not clear. In the regulations, the concept of nationalism is placed within the concept of religiousness. In this respect, the old instruction reflects the transition period from a 
multinational state to a national state. Some changes and simplifications were made in the 1923 edition of the Instruction due to the abolition of the sultanate and the declaration of the Republic and it was used until 1929. Until this date, important reforms were made in the transition to the national state and the ideology of the national state was adopted. The Act on Unity of Education, which is the basis of the national education policy, was enacted. The current instruction taken over from the Ottoman Empire was insufficient.

The Ministry of Education sent a letter to the provincial organizations in 1925 and asked for an opinion on the changes that should be made on the current instruction. The staff who declared the republic acted in accordance with its ideology with this practice. Undoubtedly, the provincial organizations are the cadres who will implement the instruction and are aware of the social situation of the country. For this reason, it is aimed to arrange the national education system in accordance with the realities of the country while asking for an opinion from the provinces by the ministry. Change proposals have been received from almost every article of the directive from the provincial offices. Proposals are generally changes in accordance with the national state ideology. No proposal regarding the upbringing of the religious generation included in the old regulations was included in the documents examined. With this aspect, it can be said that generations that have adopted a more secular education approach have grown up with the new method developing in the Ottoman Empire. As a result of these studies carried out with the provincial organizations, a new General Instruction for Primary Schools was published in 1929. The change proposals from the provincial organizations were considered important by the ministry and 1929 instruction was prepared in line with the demands. While there is clearly an emphasis on Turkish nationalism in the new instruction, there is no emphasis on raising the religious generation in the old instruction. New items were also added at the ministry's own initiative, which is not included in the proposals of the provincial organizations. The items under the titles of education and training, education activities in schools, sanitary activities and services in schools are the items that do not offer. In the context of the concept of national education, importance was given to the development of national emotions, to raise a skilled, equipped generation, as well as to be healthy and strong, and to try to make it a state policy. Consequently, the Ministry of Education, which prepared the First Schools Instruction taking into account the requests for changes from the provincial organizations, contributed not only theoretically but also practically to establish a national state and to establish a national education policy.

\section{Giriş}

19. yüzyılda milli veya modern devlet anlayışıyla birlikte eğitim anlayışı değişmeye başlamıştır. Bu süreç Avrupa'da Reform, Rönesans, Hümanizm, Metod, Aydınlanma ve Endüstrileşme çağlarının yaşanmasıyla ortaya çıkmış, dönemin düşünürleri eğitim hakkında yeni görüşler ileri sürmüşlerdir. Dogmatik eğitim anlayışından aristokratik, bireysel, sistematik, 
akılcı, milli eğitim ve öğretim arayışlarına geçilmiştir (Aytaç, 1992: 97-299). Bu süreçte yaşanan sosyal ve ekonomik gelişmeler eğitime yansımış, ciddi bir eğitim literatürü oluşmuştur. 19. yüzyılda sosyal ve ekonomik gelişmeler Fransız İhtilali ile kırılma noktasına ulaşmış, eşitlik, özgürlük, milliyetçilik fikirleri mevcut siyasi ve sosyal düzenleri yıkmıştır. Milli devletler milli eğitim politikası oluşturmaya başlamışlar, genel halk eğitimine önem vermişlerdir. Eğitim devletin görevi olarak görülürken devletler eğitim politikaları geliştirmeye çalışmışlardır (Tezcan, 1985: 67-69).

Bu yüzyılda dağılma sürecine giren Osmanlı Devleti'nde ise başlangıcından itibaren Müslüman Türk halkının eğitiminde sıbyan, medrese gibi geleneksel eğitim kurumları var olmuştur. Ancak buralarda sadece dinsel eğitim verilmiş, değişen dünya koşulları karşısında yetersiz kalmışlardır. Dağılmaya başlayan Osmanlı Devleti'ni kurtarmanın bir yolu olarak birçok alanda olduğu gibi eğitim alanında da ıslahatlar yapılmıştır. Böylece klasik dönemde çağdaşları gibi belirli bir eğitim politikası yok iken artık eğitim politikası oluşturmaya çalışmıştır. Devletin kurucu unsuru olan Müslüman Türklerin eğitimi için ilk önce rüştiye mektepleri açılmıştır. 1847'de çıkarılan Etfalin Talim ve Tedris ve Terbiyelerini Ne Vechile İcra Eylemeleri Lazım Geleceğine Dair Sıbyan Mekatib-i Haceleri Efendilerine İta Olunacak Talimat'a göre rüştiyeler ilköğretimin üst seviyesi olarak görülmüş, 4 yıllık sıbyan eğitimi üzerine 2 yıllık rüştiye eğitimi kurulmuştur (Akyüz, 1994: 1-47). Bu talimat bir yönüyle ilkokul yönetmeliği bir yönüyle ilkokul programı gibi olup 1869 tarihli Maarif-i Umumiye Nizamnamesi'ne kadar yürürlükte kalmıştır (Binbaşıŏlu, 2005: 56). Medrese eğitim sistemi dışında kurulan rüştiyelerde pozitif bilimler verilmek istenilmiş ve buralara çağdaş bilgi ve beceriyle donanmış öğretmen yetiştirmek için Darülmuallimin/Erkek Öğretmen Okulu açılmıştır. Nitekim Darülmuallimin'in açılma gerekçesinde mevcut sıbyan mektebi hocalarının rüştiye mektebinin derslerini özellikle matematik ve öteki yeni dersleri okutamadıkları vurgulanmıştır (Akyüz, 2006: 17-58; Unat, 1964: 31). Rüştiyelerde başlayan eğitim ve öğretimde ders kitapları, araç gereçlerinde yapılan yeniliklere usûl-ı cedid denmiştir. Bir süre sonra üst seviyedeki eğitimin iyi olabilmesi için daha alt seviyedeki eğitimin ıslah edilmesi gerektiği anlaşılmış, usûl-ı cedid sıbyan mektepleri için geliştirilmeye başlanmıştır. Usûl-ı cedidi yaygınlaştırmak isteyen Osmanlı sıbyan ve rüşdiyeleri medreselerin bağlı olduğu Şeyhülislamlığa değil 1846 yılında kurulan Mekatib-i Umumiye Nezareti'ne bağlamıştır. 1847 talimatında sıbyan mektepleri için yeni usuller varsa da sıbyan mekteplerinde yeni usulün geliştirilmesi daha sonradır (Demirtaş, 2007; Ergin, 1977: 465). Düzensizlik ve yetersizliği basına da yansıyan sıbyan mekteplerini (Hayta, 2018: 284) ıslah etmek için usûl-ı cedid üzere eğitim veren numune ibtidaileri kurularak yaygınlaştırılmıştır (Demirtaş, 2007; Ergin, 1977: 465). Yeni ibtidailere öğretmen yetiştirmek için 1868'de Darülmuallimin-i sıbyan/Sıbyan Öğretmen Okulu açılmıştır (Unat, 1964: 33; Koçer, 1992: 79; Öztürk, 1996: 7-9; Ünal; Birbudak, 2013: 65-68). 1869 Maarif-i Umumiye Nizamnamesi ile sıbyan mekteplerine Tarih, Coğrafya, Hesap gibi dersler ve sıra, kara tahta, tebeşir, harita, yer küresi, öğretmen kürsüsü gibi araç gereçlerin girmesiyle usûl-ı cedid gelişmeye devam etmiştir (Akyüz, 2012: 209). Sıbyan Öğretmen Okulları 1875'ten itibaren taşrada yaygınlaştırılmaya çalışılmıştır (Akyüz, 2012: 250-251). Bu dönemde eğitimde yeni anlayışın bir diğer boyutu olan kadın eğitimine önem verilmiştir. Kız çocukları için geleneksel sıbyan mektebi dışında yeni mektepler açılmaya başlamıştır. Illk kız rüştiyesi 1859'da kurulmuş, kızlar için meslek eğitimi başlamıştır (Kurnaz, 1991: 18; Karaca, 2010: 137; Akyüz, 2012: 172). 1869 Maarif-i Umumiye 
Nizamnamesi gereğince kızlar için de usul-ı cedid üzere eğitim verecek ibtidailer açılmıştır. 1870 'de ise Darülmuallimat/Kız Öğretmen Okulu açılarak yeni usul yaygınlaştırımaya çalışılmıştır (Unat, 1964: 31). Usûl-ı cedid hareketi aslında Avrupa'nın Reform ve Rönesans hareketine benzer bir Türk aydınlanma hareketidir (Temizyürek, 2014: 365-381).

İbtidailer geliştirilirken diğer yandan bu okulların bağlanacağı Maarif Nezareti 1857'de kurularak teşkilatını geliştirmeye çalışmıştır ("Maarif Nezareti'nin Tarihçesi", 1316: 17-37). II. Abdülhamit döneminde 1869 'da Maarif-i Umumiye Nizamnamesiyle teşkilatlanma devam ettirilmiş, taşrada maarif idareleri, meclisleri kurulması kararlaştırılmıştır. Nizamname tam olarak her tarafta uygulanamadıysa bile nizamname ile ilköğretimin amacı salt dini alana ait bir öğretim kademesi olmaktan çıktığı gibi sadece okuryazarlık öğretmek olduğu görüşü ret edilerek daha sistematik bir eğitim anlayışına geçilmiştir (Nurdoğan, 2005: 140; Binbaşığlu, 2014: 222; Unat, 1964: 18-26). II. Abdülhamit döneminde ilköğretim geliştirilmeye çalışılmış, 1876-1895 arasında ülke genelinde 18947 olan ilk mekteplerin sayısına 9649 adet ilave edilmiş, 14 ilk Öğretmen Okulu açılmıştır (Alkan, 2011: 49). Nizamname birkaç ufak değişiklikle 1913 tarihli Tedrisat-ı İbtidaiye Kanun-ı Muvakkatı́nın çıkmasına kadar yürürlükte kalmıştır. Bu teşkilatlanmanın amacı şüphesiz özellikle ilköğretimi geliştirmek ve denetlemektir. 1869'dan 1913 tarihli Tedrisat-ı İbtidaiye Kanun-u Muvakkatı'nın çıkışına kadar yapılan yazışmalarda ve talimatnamelere göre eğitim yaşına gelmiş çocukların "mütedeyyin", "vatanperver", "mukaddem" ve "gayur" olarak yetiştirilmesi ibtidailerin hedefidir (Nurdoğan, 2005: 140). 1909'a kadar II. Abdülhamit dönemi olan bu dönemde ilköğretimin amacı onun İslamcılık ve Osmanlıcılık siyasetine de uygundur (Binbaşıoğlu, 2014:221; Akyüz, 2012: 225-226).

1913 Tedrisat-ı İbtidaiye Kanun-u Muvakkatı, on fasıl olup 101 maddedir. Kanunun çalışma açısından önemli olan dördüncü maddesinde tedrisat-ı ibtidaiyeye mahsus mekteplerin teşkilat ve tanzimatına müteallik olan nizamname ve talimatların Meclis-i Kebir-i Maarif tarafından hazırlanacağı belirtilmiştir. Nitekim 1915'de Mekatib-i İbtidaiye-i Umumiye Talimatnamesi çıkarılmıştır ("Mekatib-i ibtidaiye-i Umumiye", 1331). Bu talimatnamenin ufak değişikliklerle 1923 yılında yeni bir baskısı yapılmıştır (“ilk Tedrisat Talimatnamesi”, 1339). Fakat yeni bir devlet kurulduğu ve 1924'te Tevhid-i Tedrisat Kanunu kabul edildiği için ilköğretimin yeni bir anlayışla ele alınması gerekmiş ve mevcut talimatname yetersiz kalmıştır. 1925 yılında Maarif Vekâleti taşra birimlerinden yeni yapılacak talimatname için görüş istemiştir. Aşağıda açıklanacak olan bu görüşlere geçmeden önce 1915 talimatnamesini tanıtmak ve 1923'te yapılan değişiklikler hakkında bilgi vermek faydalı olacaktır. Daha sonra 1929 'da yapılan yeni talimatname eskisi ile kıyaslanarak değerlendirilmiş ve süreç açılanmaya çalışılmıştır.

\section{Yöntem}

\section{Araştırma Deseni}

Çalışmada 1915 yılında çıkarılan ve ufak değişikliklerle 1929 yılına kadar kullanılan illk Mektepler Talimatnamesi'nin tarihi süreci açıklanmaya çalışılmıştır. Bu süreci açıklarken 
tarama modeli (Karasar, 1998: 77) kullanılmış olup elde edilen veriler nitel çalışma (Yıldırım ve Şimşek, 2008: 19) yöntemiyle değerlendirilmiştir.

\section{Veri Toplama Araçları}

Çalışmanın ana konusu olan ilık Mektepler Talimatnamesi Osmanlı döneminde kitapçık olarak yayımlanmış olup 1923 baskısı dâhil olmak üzere Millet Kütüphanesi ile Atatürk Üniversitesi Kütüphanesi'nde bulunmaktadır. Kütüphanelerden elde edilen talimatnamenin yenisi 1929 tarihli olanı ise Milli Eğitim Bakanlığı tarafından bir kitapçık olarak yayımlanmıştır. Elde edilen bu talimatnamelere ilave olarak Cumhurbaşkanlığı Devlet Arşivleri, Cumhuriyet Arşivi Milli Eğitim Bakanlığı'na ait belgeler üzerinde yapılan çalışma ile talimatnamenin değiştirilmesine ilişkin taşra teşkilatlarından gelen yazışmalara ulaşılmıştır. Ayrıca Maarif Salnameleri, TBMM Zabıt Cerideleri ile konuyla ilgili bazı telif çalışmalar kullanılmıştır. Araştırmada doğrudan insanlar üzerinden herhangi bir veri toplanmadığı için bu çalışma Etik Kurul Onayı gerektirmemektedir.

\section{Verilerin Analizi}

Çalışmanın konusunu oluşturan illk Mektepler Talimatnamesine giden süreç Maarif Salnameleri ile çeşitli telif eserlerden yararlanarak incelenmiştir. Osmanlı'da 1915'te çıkarılan talimatname ile ilköğretime sistematik ve bütüncül bir bakış açısı getirilmiştir. Birinci Dünya Savaşı ve Milli Mücadele'nin sona ermesi ve Cumhuriyet'in ilan edilmesinden sonra 1923'te talimatname yeniden basılmıştır. 1915 ile 1923 tarihli baskılar birbiri ile karşılaştırılmış farklııılar ortaya konulmuş ve sebepleri açıklanmaya çalışılmıştır. Bu farklılıklar siyasi yapının değişmesi Cumhuriyetin ilan edilmesi ile ilgilidir. Ancak mevcut talimatname yeterli gelmemiş ve 1925 yılında talimatnamenin değiştirilmesi hakkında Milli Eğitim Bakanlığı taşra teşkilatlarından görüş istemiştir. Konu ile ilgili Bakanlık ve taşra teşkilatlarına ait yazışmalar transkript edilmiştir. Daha sonra taşra teşkilatlarının değişmesini en çok istedikleri maddeler ve sebepleri ortaya konulmuştur. Bu değişiklik talepleri siyasi yapının değişmesi ile ilgili olduğu kadar mevcut sosyal ve ekonomik sebeplerle de ilgili olduğu görülmüştür. 1929 yılında yapılan yeni talimatnameye taşra teşkilatlarının görüşlerinin yansıyıp yansımadığı incelenmiştir. Söz konusu talepler yeni talimatnameye yansımıştır. Ayrıca Bakanlık taşra teşkilatlarının talepleri arasında bulunmayan yeni maddeler eklemiştir. Illaveten 1929 talimatnamesi ile eski talimatname birbiriyle kıyaslanmış farklılık ve benzerlikler değerlendirilmiş ve diğer bulgularla birlikte sonuç kısmına yansıtılmıştır.

\section{Bulgular}

\section{Mekatib-i İbtidaiye-i Umumiye Talimatnamesi ve 1923'te Yapılan Değişiklikler}

Talimatname 1331 (1915)'de Matbaa-i Amire'de basılmış, 125 madde olup 29 sayfadır. Son sayfada tarih-i neşri 2 Ramazan 1333 ve 2 Temmuz 1331 (15 Temmuz 1915) olarak geçmektedir. Millet Kütüphanesinde 264 numara ile kayıtlıdır. 1923 tarihli baskısı da aynı şekilde 125 madde olup 29 sayfadır. Sonunda yoklama defteri, demirbaş eşya defteri, mektep kütüphane defteri, umumi sicil defteri şeklinde örnek tablolar eklenmiştir. Aşağıda 
talimatnamenin her bir faslı ve 1923'te yapılan değişiklikler hakkında kısa bilgiler verilmiştir. Sonraki kısımda irdelenecek olan tadilat tekliflerinin talimatnamenin hangi kısımlarıyla ilgili olduğunun anlaşılabilir hale gelmesi için fasıllar ve 1923 değişiklikleri hakkında genel bilgi verilmesi gerekli görülmüştür;

Talimatnamenin ilk sayfasında Mekatib-i İbtidaiye-i Umumiye Talimatnamesi yazılı olup buna bugün için Illk Mektepler Genel Yönetmeliği denilebilir. İkinci sayfasında talimatname içinde yer alan fasıllar başlıkları ve sayfaları fihrist olarak verilmiştir. Talimatnamenin önsözünde aşağıdaki ifadelerde ilköğretimin hedefi ortaya konulmuştur (“Mekatib-i İbtidaiye-i Umumiye”, 1331: 3);

23 Eylül 1329 tarihli Tedrîsât-ı İbtidâiyye Kanun-ı Muvakkatının beşinci maddesine göre mekâtib-i ibtidâiyyenin hedefi mecbûriyyet-i tahsîliyyeye tâbi' olan etfâli hayat için en ziyâde lâzım olan ma'lûmâta mazhar etmek, mütedeyyin ve vatanperver, mukaddem ve gayyur birer insan olarak yetiştirmektir. Mekâtib-i ibtidâiyye tahsil ve terbiye husûsundaki vazîfesini gittikçe iyi bir sûrette îfâ ederse memleket fikir, ahlâk, iktisâd cihetiyle günden güne yükselir. Bu teâlî ve terakki sayesinde de din ve milliyet husûslarında hüviyet-i mahsûsasını muhâfazaya muvaffak olur. Mekteb sıralarındaki yeni nesil hem an'anât-ı diniyye ve milliyeyi muhâfazaya hem de şerâit ve ihtiyâcât-ı hâzıra ile te'lîf-i nefse alıştırılır.

Talimatnamedeki bu ifadelerden 19. yüzyıldan beri dağılmaya başlayan Osmanlı Devleti'ni kurtarma amacını ve çabasını görmek mümkündür. Bu bağlamda bakıldığında ilköğretimin hedefini açıklayan hayat için gerekli bilginin edindirilmesi, dindar, vatanperver, öncü, gayretli insan olarak yetiştirilmesi dönemin koşullarını yansıtmakta olup ülkeyi yıkılıştan kurtarmak amacındadır. Diğer taraftan "din ve milliyet hususlarında hüviyet-i mahsusasını muhafaza" ya da "an'anât-ı diniyye ve milliyeyi muhafaza" ifadelerinde çok açık olmasa da milliyetçilik vurgusunu görmek mümkündür. Dini ve milli özellikleri korurken şerait ve ihtiyâcât-ı hazıra/mevcut şartlar ve ihtiyaçlar ile dini ve milli özellikleri çocuğun şahsında te'lîf ettirmek/uzlaştırmak amaçlanmıştır. Osmanlı'nın son döneminde yeni ortaya çıkmış olan Türkçülük fikri o sırada iktidarda olan İttihat Terakki Fırkası'nın eğitim politikasına talimatname bağlamında yansımıştır. Bu bağlamda Türklerin Müslüman olmasıyla gelenekselleşen din ve devletin ikiz kardeş olduğunu (Yüksel, 2009: 51) ifade eden, Osmanlı belgelerinde sıkça karşılaşılan "din ü devlet" kavramlarının yerini çağın gelişmeleri karşısında din ve milliyet kavramları almaya başlamıştır. Milli kimlik, ön planda olan dindarlığın içine yerleştirilmiştir. 1923 baskısında hemen aynı cümlelerle amaç verilmiş, bazı kelimelerin yerine sadesi veya eş anlamlısı kullanılmıştır, hatta talimatnamenin ismi İlk Tedrisat Talimatnamesi şeklinde biraz daha sadeleştirilmiştir ("ilk Tedrisat Talimatnamesi”, 1339: 3).

Talimatnamenin birinci fasılında 1-6. maddelerde okula kayıt ve kabul şartları belirlenmiştir ("Mekatib-i ibtidaiye-i Umumiye”, 1331: 4-5). Bu maddelerde okula kayıtların ne zaman, kim tarafından yapılacağı, bir mektepten başka bir mektebe nakil işlemleri, kayıt için gerekli evraklar, hususi mekteplerde ve evde tahsil görenlerin ibtidailere kabul şartları yer almıştır. 1923 tarihli baskısında herhangi bir değişiklik görülmemiştir ("ilk Tedrisat Talimatnamesi", 1339:4-5). 
İkinci fasıl 7-11. maddeler olup ders müddeti, resmi ve tatil günleri hakkındadır ("Mekatib-i ibtidaiye-i Umumiye", 1331: 5-6). Bu fasılda tek değişiklik tatil günleri arasında sayılan padişahın tahta çıkışı saltanat kaldırıldığı için 1923'te talimatnameden çıkarılmıştır (“ilk Tedrisat Talimatnamesi", 1339: 5-6).

Üçüncü fasıl ders vakitleri hakkında olup 12-19. maddelerdir ("Mekatib-i İbtidaiye-i Umumiye", 1331: 6-8). Bu kısımda beden derslerinde askeri talimlerin yaptırılması dikkat çekmektedir. Beden eğitimi çağdaş bir eğitim anlayışı olmakla birlikte ilköğretimde askeri talim uygulaması ülkenin yakın savaş tehdidi veya savaşta olmasıyla yakından ilgilidir. Bu fasıl 1923 baskısıyla karşılaştırıldığında bir değişiklik yoktur (“ilk Tedrisat Talimatnamesi”, 1339: 6-8).

Dördüncü fasıl sınıfların taksimi ile ilgili olup 20-22. maddelerdir ("Mekatib-i İbtidaiyei Umumiye", 1331: 8-9). Bu maddelerden ders ve sınıf düzenlemesinden muallim ve bina yetersizliğini görmek mümkündür. Amaç her sınıf için ayrı öğretmen olmakla birlikte yeterli öğretmen ve bina olmadığı için devlet elindeki mevcudu verimli şekilde düzenlemeye çalışmıştır. 1923 baskısında tek değişiklik padişaha dua kısmı çıkarılmıştır ("ilk Tedrisat Talimatnamesi", 1339: 8-9).

Beşinci fasıl dersler hakkında olup 24-33. maddelerdir ("Mekatib-i İbtidaiye-i Umumiye", 1331: 9-11). Bu fasılda derslerin resmi müfredata ve nezaretin talimatlarına göre yapılacağı belirtilirken dersin gayesinin talebeye söylenmesi, ödevlerin kontrolü, talebenin dikkatini derse çekme konuları ayrıntılı olarak yer almıştır. Bu fasıl derslerin en iyi şekilde yapılmasıyla pedagojiyle ilgili olup bu maddelerin bir kısmı bugün dahi güncelliğini korumaktadır. Bu fasılda 1923 baskısında herhangi bir değişiklik yapılmamıştır ("ilk Tedrisat Talimatnamesi", 1339: 9-11). Altıncı fasıl yazılı ödevler ve yoklamalar hakkında olup 34-39. maddelerdir. Bu kısımda ödevlerin kontörlü için oldukça ayrıntılı hükümler konulmuştur ki bir öğretmenin bütün öğrenci ödevlerini talimattaki kadar ayrıntılı olarak kontrol etmesi pek te mümkün görülmemiştir. Yedinci fasıl terbiye başlıklı olup 40-48. maddelerdir. Burada düzen, temizlik, saygı, ibadetlerin yaptırıması ile fikri, hissi, iradi terbiyenin nasıl yapılacağı açıklanmıştır. Sekizinci fasıl talebenin ödüllendirme ve cezalandırılması ile ilgili olup 49-54. maddelerdir ("Mekatib-i İbtidaiye-i Umumiye", 1331: 11-14). Bu fasıllar öğrencinin en iyi şekilde eğitilip öğretilmesi ile ilgili pedagojik maddeler olup yukarıda açıklanan dindar ve milli hüviyeti koruma amacına uygun olarak düzenlenmiştir. 1923'te basit kelime değişikliklerinden başka bir şey yapılmamıştır (“ilk Tedrisat Talimatnamesi”, 1339: 11-15). Dokuzuncu fasıl imtihanlar ile ilgili olup 55-64. maddelerdir (“Mekatib-i ibtidaiye-i Umumiye”, 1331: 14-17). Sınavların yapılışında sıkı bir denetleme sistemi kurulmaya çalışıldığı söylenebilir. 1923'te bu fasılda muallimlerin verdikleri puanların denetlenmesindeki başmuallim faktörü kaldırılmış, iki dersten ortalaması düşük olanlar için ikmal bir nevi bütünleme imtihanı getirilmiştir ("illk Tedrisat Talimatnamesi", 1339: 15-18).

Onuncu fasıl cüzdanlar, nakil ilmühaberleri ve tasdiknamelerin nasıl, ne zaman doldurulup, nereye verileceği hakkında olup 65-70. maddelerdir ("Mekatib-i íbtidaiye-i Umumiye", 1331: 17-18). Nakil ve tasdiknameler ile ilgili bu maddeler, arşivlemek gibi teknik konularla ilgili olup 1923 yılında değişiklik yoktur (ilk Tedrisat Talimatnamesi, 1339: 19-20). On birinci fasılda başmuallimin görevleri 71-87. maddelerden ibarettir ("Mekatib-i İbtidaiye-i Umumiye", 1331: 18-21). Maddeler başmuallimin görevini açıklarken başmuallimin de 
denetlendiği bir sistem ortaya koymuştur. Bu fasılda 1923 yılında esası değiştirmeyen bir iki kelime ilavesinden başka değişiklik yoktur. ("ilk Tedrisat Talimatnamesi”, 1339: 19-21). On ikinci fasıl muallimlerin görevini açıklamakta olup 88-103. maddelerdir ("Mekatib-i İbtidaiye-i Umumiye", 1331: 21-23). Bu maddelere göre başmuallimlerin muallimleri denetlediği görülmektedir. Ayrıca muallimlerin öğrencilerinin karşısındaki davranışlarıyla ilgili maddeler bu gün dahi geçerliliğini korumaktadır. Devlet muallimlerde bir meslek ahlakı geleneği oluşturmaya çalışmıştır denilebilir. 1923'te birkaç kelime değişikliğinden başka önemli bir değişiklik yoktur (“ilk Tedrisat Talimatnamesi”, 1339: 22-24). On üçüncü fasıl mektep eşyası ve malzemeleri hakkında olup 104-108. maddelerdir ("ilk Tedrisat Talimatnamesi", 1339: 23-25). Bir kısmı halen okullarda mevcut eşyalar olup musluklu küp gibi eşyalar dönemin maddi imkânlarının ne derecelerde az olabildiğini de yansıtmaktadır. 1923 yılında ufak tefek kelime değişikliklerinden başka bir değişiklik yapılmamıştır (“ilk Tedrisat Talimatnamesi”, 1339: 2426). On dördüncü fasıl ders malzemesi olup 109. maddedir ("Mekatib-i ibtidaiye-i Umumiye", 1331: 25). 1923 tarihli baskıyla karşılaştırıldığında değişiklik yoktur ("ilk Tedrisat Talimatnamesi", 1339: 26-27). On beşinci fasıl ders malzemeleri, cetveller ve evrak hakkında olup 110. maddedir (“Mekatib-i ibtidaiye-i Umumiye”, 1331: 26). 1923'te herhangi bir değişiklik yapılmamıştır. Bu defterlere benzer defterler günümüzde de tutulmaktadır ("ilk Tedrisat Talimatnamesi", 1339: 26-27). On altıncı fasıl numune ibtidaileri hakkında olup 111120. maddelerdir ("Mekatib-i ibtidaiye-i Umumiye”, 1331: 27-28). Bu maddelere bakarak numune mekteplerinin ülkede asıl geliştirilmek istenen mektepler olduğunu söylemek mümkündür. 1923 yılında herhangi bir değişiklik yoktur (“ilk Tedrisat Talimatnamesi”, 1339: 27-29). On yedinci fasıl talebe ve muallimler olup 121. maddedir ("Mekatib-i ibtidaiye-i Umumiye", 1331: 28). Bu talimatnamenin erkekler gibi kadın talebe, muallim ve başmuallim ve müdürler hakkında da geçerli olduğu ifade edilmiştir. 1923'te değişiklik yoktur (“ilk Tedrisat Talimatnamesi”, 1339: 29). On sekizinci fasıl ek hükümler olarak 122-125. maddelerdir (“Mekatib-i ibtidaiye-i Umumiye”, 1331: 29). Talebenin mektebi bitirme yaşı ve önceki talimatnamenin geçersizliği hakkındadır. 1923 yılında herhangi bir değişiklik yapılmamıştır ("ilk Tedrisat Talimatnamesi", 1339: 29).

Talimatname maddeleri genel olarak bulunduğu dönemin sosyal, siyasal, dinsel anlayışını yansıtmaktadır. Yukarıda ifade edilen 1915 tarihli talimatnamenin 1923 baskısıyla aralarında büyük farklar yoktur. Mesela ilköğretimin amacı hemen aynı şekilde bazı cümleler biraz daha vurgulu, sadeleştirilmiş, ya da saltanat kaldırıldığı için padişah ile ilgili maddeler çıkarılmıştır. Talimatnamenin bütününde dindar nesil yetiştirmek yanında açıkça Türk kelimesi kullanılmamakla birlikte gelişmekte olan Türk milliyetçiliğinin izlerini bulabiliriz. Talimatnamenin 1923 baskısının daha sade bir Türkçe ile yazıımış olmasını Türk milliyetçiliği fikrinin gelişme yönünde yol kat etmesi ve yeni Türkiye Cumhuriyeti Devleti'nin bu fikri ideoloji olarak benimsemesiyle ilgilidir. Millî Mücadeleden başarıyla çıkılmış, milli bir devletin kurulmaya çalışıldığı, Cumhuriyetin ilan edildiği yılda yeniden basılan talimatnamenin bazı hükümlerinin değiştirilmiş olması, sadeleştirilmesi hep bu siyasi ve askeri değişiklikler ile ilgilidir.

3 Mart 1924 tarihinde Tevhid-i Tedrisat Kanunu ile dini eğitim dâhil olmak üzere bütün eğitim kurumları Maarif Vekâlet'ine bağlanmıştır. Dolayısıyla mevcut talimatname yetersiz kalmış, yeni bir ilk mektepler talimatnamesi gerekmiştir. Maarif Vekâleti 4 Nisan 1925 gün 
11143/886 numaralı yazısıyla bütün taşra teşkilatlarına talimatnamenin değiştirilmesi gereken maddeleri hakkında görüş belirtmesini istemiştir (MEB, 1925).

\section{Talimatnamenin Değiştirilmesi ile ilgili Görüşler (1925)}

Talimatnamenin değiştirilmesi ile ilgili olarak Cumhurbaşkanlığı Devlet Arşivinin Cumhuriyet Arşivi kısmında Millî Eğitim Bakanlığı'nın 1925 yılına ait iki klasörü üzerinde çalışma yapılmıştır. Klasörün birisi 146, diğeri 109 sayfa (MEB, 1925) olup toplam 255 sayfa transkript edilmiştir. Bu konudaki çeşitli illerden gelen yazışmalar incelenmiş ve her bir madde üzerinde ayrıntılı tadilat teklifleri yapıldığı görülmüştür.

Yukarıda künyesi verilen klasörlerdeki tadilat teklifleri her yerden aynı şekilde istenmemiştir. Bazen doğrudan ilgili maddenin numarası verilerek sadece istenilen değişiklik belirtilmiş, bazen ilave madde şeklinde istenilmiştir. Bazen de değiştirilmesi istenen maddenin numarası verilmeden genel değişiklikler şeklindedir. Bunların dışında tadilat teklifleri bazen birkaç basit kelime değişikliği şeklinde olurken bazen birden fazla maddenin tadilat teklifi gerekçesi yazılarak uzun açıklamalar şeklinde gerçekleşmiştir. Her zaman değişiklik gerekçesi belirtilmemiştir. Burada sadeleştirme veya daha açık hale getirme şeklinde istenen, farklı yerlerden gelen çok sayıdaki tadilat teklifleri üzerinde fazla durulmamıştır. Ancak bunun dışında ülkenin mevcut sosyal ve siyasal koşulları ile ilgili değişiklik talepleri eğitim sistemi kurma arayışlarını etkilediği için daha dikkat çekici bulunmuştur.

Talimatnamedeki okula kabul ve kayıt süresinin uzatılması veya sınır konulmayarak değiştirilmesi en çok istenen madde olmuştur (MEB, 1925). Bunun sebebi henüz bir tarım ülkesi olan Türkiye'de çocukların genellikle çiftçi, bahçıvan çocukları olup tarımsal faaliyetlerin çok olduğu hasat zamanında okula kayıt ve kabul başladığı sırada çocukların ailelerine yardım ediyor olmalarıdır ki bu durum yazışmalarda açıkça belirtilmiştir. Kayıt ve kabul dersler başlayınca bittiği için çocuklar okula devam edememektedirler. Aynı sebeplerle talimatnamede 42 hafta olan ders süresinin köylerde 36 haftaya indirilmesi; köyler için ayrı bir müfredat programı ve talimatname yapılması istenmiştir.

Anormal ve hasta çocukların okula başlattırılmasıyla ilgili farklı ifadelerle birçok tadilat teklifi gelmiştir (MEB, 1925). Tadilat teklifinin yapıldığı 1925 yılı savaşın yıkıntılarının henüz tamamen ortadan kalkmadığı, salgın hastalıkların yaygın olduğu ve hükümetin sağlık sorunlarını çözmeye çalıştığı bir dönemdir ("TBMM Zabıt Ceridesi”, 1925:299-301). Dolayısıyla hasta ve anormal çocuklarla ilgili tadilat teklifleri ya da okullarda diş muayenesi yapılması gibi teklifler sağlıklı bir nesil yetiştirmek amacını yansıtmıştır. Bu konudaki tadilat genellikle birinci fasılda okula kayıt ve kabul kısmıyla ilgili olup 1 numaralı madde üzerinde yoğunlaşmıştır. Yine çocukların mektebe sekiz yaşında başlattırı masının istenmesi de savaş yıllarının getirdiği bakımsızlık sebebiyle yeteri kadar gelişememelerinden kaynaklanmıştır. Benzer şekilde özellikle köylerdeki çocukların aşılattırılmasının mümkün olamadığının vurgulanması sağlık sorunlarının mevcudiyetini göstermektedir.

Kayıt sırasında çocuğun yaşı ile fiziksel görüntüsü arasında fark varsa böyle çocukların fiziksel görüntüsüne uygun olan sınıflara yerleştirilmesi istenmiştir. Ya da yaşı aslında büyük fakat nüfusta küçük olan çocukların yerleştirilmesinde muallimlerin ortak olarak, maarif müdürünün tek başına ya da encümenin karar vermesi dışında yaşı nüfusa küçük işlenen suç 
işleyen çocukların sokağa bırakılmaması, ıslahhaneler kurulması gibi çeşitli tadilat teklifleri gelmiştir (MEB, 1925). Büyük yaş meselesi de en çok vurgulanan meselelerden olduğu görülmüştür. Bu meseleye dair tadilat tekliflerinin çok olması yine ülkenin sosyolojik koşulları ile ilgilidir. 19. yüzyılda Osmanlı'da modern anlamda başlayan nüfus kayıtlarını tutma çalışmaları Birinci Dünya Savaşı sırasında kesintiye uğramış, sağlıklı nüfus kayıtları tutulamamıştır. Yeni Türkiye Cumhuriyeti bu konularda da çalışmalara başlamıştır (Çakmak, 2009: 89-115). Bazen çocuk nüfusa büyük yazdırıırken bazen küçük yazdırılmış gerçek yaşları tam sağlıklı olarak tutulmamıştır. Tekliflerde aynı fiziksel ve ruhsal gelişimdeki çocukların aynı sınıfa yerleştirilmesi çabası günümüzde devam eden pedagojik bir uygulamadır. Taşra teşkilatlarından bu yönde gelen tadilat tekliflerinden bu meselenin yaygın olduğu anlaşılmaktadır.

Talimatnamenin imtihanlarla ilgili maddelerinde birçok farklı değişiklik teklifleri gelmiştir (MEB, 1925). Mesela evde veya hususi mektepte tahsil görmüş çocukların devlet okullarına kabullerinde sınavı sadece başmuallimin yapmasına karşı çıkılmış, bir heyet tarafından veya dersin muallimi tarafından yapılması gibi birçok yerden tadilat teklif gelmiştir ki imtihanların denetlenmesi istenmiştir. Benzer şekilde derslerde muallimlerin puan vermede haksızlık yaptığına dair bir kanaat olması durumunda başmuallimler ve mümeyyizler ile birlikte puanda düzenleme yapılması veya heyet-i talimiye huzurunda yazılı veya sözlü imtihan yapılıp öyle puan verilmesi istenmiştir. Bu istekler uygulamada sıkıntılar olduğunu işaret etmektedir. Puanlama dışında talimatnamedeki imtihan günlerinin on gün olması az bulunmuş yirmi güne, on iki güne çıkarılması, imtihanlardan önce bir hafta derslerin kesilmesi gibi istekler olmuştur. Ders puanlarının verilmesinde malumat-ı diniye ve Kuranı kerim gibi derslerin birleştirilmesi veya Türkçe dersindeki grupların ikiye ayrılması, üst sınıfa geçişte notların yükseltilmesi yönünde teklifler yapılmıştır. Bazı durumlarda ya da son sınıflara ikmal imtihanı ilave edilmesi ve süresinin belirlenmesi, asgari devam süresinin belirtilmesi yönünde teklifler gelmiştir

Cumhuriyet ilan edilmiş, milli bir devlet kurulmaya çalışıldığı bu dönemde ilköğretimde tatil günlerinin de buna uygun hale getirilmesi istenmiştir (MEB, 1925). Büyük bir Milli Mücadele neticesinde kurulan yeni Türk Devleti'nin kuruluşundaki önemli kilometre taşı olan Dumlupınar zaferi günü ile Cumhuriyetin ilanı gününün eklenmesi birçok yerden teklif edilmiştir. Bu tür günlerin resmi tatil yapılması yeni kuşaklara milli devlet ideolojisini benimsetmek içindir. Yine milli devlet anlayışının bir yansıması olarak bayrak merasiminin sadece erkek mekteplerinde değil kız mekteplerinde de yapılması; Türkçe lisanının zorunlu olması; vatan, coğrafya, tarih derslerinin ilavesi; aile ve çevreden çocuğa gelen hurafelerin ret edilmesi ve milli gelenek ve Türklük duygularının güçlendirilmesi; mektep salonlarının süslenmesinde Osmanlı tarihinde geçen şahıslar yerine Sakarya, İnönü kahramanlarının resimlerinin asılması; Cumhuriyetçilik ve halkçılık ilkelerini takviye edecek terbiyevi esasların talimatnameye ilave edilmesi ve muallimlere bu hususta bir rehber verilmesi şeklindeki teklifler (MEB, 1925) milli devlet anlayışıyla ilgili olduğu kadar laik bir devlet kurma arayışlarıyla da ilgilidir. Yazışmalarda milliyetçilik yönünde bu tür teklifler bulunmasına karşın dinsel eğitim yönünde teklifler ise bulunmamaktadır.

Tedrisat-ı İbtidaiye Kanunu'nun üçüncü faslı gereğince maarif teşkilatının bir parçası olan (Özalp, 1982: 88-90) ve görevleri talimatnamenin bazı maddelerinde geçen maarif 
meclisleri ile ilk tedrisat meclislerinin bazı yetkilerinin değiştirilmesi ile ilgili değişiklik talepleri söz konusu olmuştur (MEB, 1925). Derslerin başlama ve bitiş günlerinin belirlenmesinde ilk tedrisat meclislerinde makul olmayan istekler ortaya çıktığı, bunun Maarif Vekâleti tarafından belirlenmesi istenmiş, görevine gelmeyen, geç gelen muallimlere ceza verilmesindeki yetkinin ilk tedrisat meclisinin kararına bırakılmasına karşı çıkılmış, tedrisat meclislerinin fazla ceza veya hiç cezalandırmama gibi kararlar verdiği ifade edilmiştir. Maarif meclislerinde ise başmuallimin encümen tarafından verilecek emirleri yerine getireceğine dair ifadenin, maarif müdürü olmayan yerlerde encümen reisi tarafından verilecek emirleri yerine getireceği şeklinde düzeltilmesi istenmiştir. Maarif encümen üyelerinin genellikle ilkokul mezunu bile olmaması dolayısıyla sıkıntı yarattığı için tahsil şartı getirilmesi, maarif encümenlerinin muallimlere altı gün izin vermesi yerine üç gün izin vermesi ya da konuyla ilgili 87. maddenin değiştirilerek maarif encümenleriyle muallimlerin ilişkisinin yeniden düzenlenmesine yönelik teklifler yapılmıştır.

Derslerin verilişinde bazı pedagojik içerikli değişiklik teklifleri de gelmiştir (MEB, 1925). Mevcut talimatnamenin 25. maddesindeki bir saatte verilecek dersin konusu sınırlı ve kararlaştırılmış olmalı ifadesinin, müfredat programlarına uygun ders kitaplarının büyük âlimler tarafından değil de çocuk ruhundan anlayan kimseler tarafından yazılması şeklinde değiştirilmesi istenmiştir. Yine 26. maddedeki dersin gayesi ve ne öğreneceğinin talebeye en baştan söylenmesinin her ders için uygun olmadığı değiştirilmesi gerektiği ifade edilmiştir. 45. maddedeki talebenin fikri, hissi, iradi terbiyesiyle ilgili maddenin zaten usul-ı talim ve terbiye talimatnamesinde bulunduğu belirtilerek tamamen kaldırılması, 38. maddedeki talebenin ödevlerinin ayrıntılı kontrol ve izahı yerine genel hataların söylenmesi şeklinde tadil edilmesi; ders usulüne dair Vekâlet tarafından bir dergi çıkarılması gibi teklifler derslerin işlenmesiyle ilgili pedagojik maddelerdir.

Sekizinci fasıldaki talebenin ödül ve cezalandırılmasıyla ilgili maddeler üzerinde de birçok değişiklik teklifi yapılmıştır (MEB, 1925). Başarılı talebeye mükâfat verilmesi için maarif idarelerinin bütçelerine bir miktar para konulması ve bu konuda köy mekteplerinin tercih edilmesi gibi. Ya da yazılı bir takdirin verilmesinin eşitlik durumunda çocuklar arasında kıskançlığı izale edip olumlu etki yapacağı belirtilmiştir. Fasıldaki talebenin cezalandırılmasında arkadaşları önünde azarlanması faydalı görülmeyen değiştirilmesi istenen maddelerden olup cezalandırmada kır gezintilerinden mahrumiyet, bir görev vermek gibi uygulamalar teklif edilmiştir. Mecburi tahsil yaşını geçmiş çocukların geçici veya kesin olarak ihraç edilmesini gerektiren suçlar ile ilgili maddenin bu tür suç işleyen 12 yaşındaki çocuklar içinde geçerli olması, yaralama durumları için daha açık ilaveler yapılması gibi farklı teklifler yapılmıştır.

Sınıfların mevcutlarının 50'den fazla olmamasına dair tadilat teklifinden sınıfların kalabalık olduğu anlaşılmaktadır (MEB, 1925). Bu meseleyi Osmanlı'dan beri gelen ekonomik sıkıntılardan ve savaş yıllarının getirdiği okul binası yetersizliğinden ayrı düşünmek olası değildir (TBMM Zabıt Ceridesi, 1921: 165-187).

Bunların dışında ders saatlerinin ve teneffüs sürelerinin uzatılması, ya da ders başlama saatlerinde mahallin özelliklerinin dikkate alınması; muhazara ve konferans günlerinin değiştirilmesi; akşam dörtten sonraki derslerin kaldırılması; ders isimlerinin son müfredat programına göre tadili; talebeye aynı tip elbise giydirilmesi; öğrenciler hakkında tutulan çeşitli 
cüzdanların doldurulma ve idareye verilme tarihlerinde değişiklik; ülkenin öğretmen ve bina yetersizliği sebebiyle mevcut tek dershaneli ve tek muallimli sınıfların en az iki muallimli hale getirilmesi; ders müfredatı talimatnamenin içinde bulunmamakla birlikte müfredatın da tadil edilmesi; mektep süresi beş yıl olarak düzenlendiği için numune mektepleriyle ilgili faslın tamamen kaldırılması ya da uzun açıklamalarla her bir maddenin tadil edilmesi; başmuallimlerin ders saatinin azaltılıp müdür unvanının verilmesi; teneffüs zamanlarının bina ve bahçenin durumuna göre düzenlenmesi; yabancı tebaya ait bir çocuğun mektebe kabulüne dair madde ilavesi; hasta olan muallimlerin rapor alması, yerine vekil muallim atanması ve bunların ücretlerinin verilmesi ve kesilmesi; belli bir alanda özel uzmanlığı olan muallimlerin farklı sınıflarda derslere girebileceğine dair maddenin muallimler arasında sıkıntıya sebep olduğu için bunun açık hale getirilmesi ve daha birçok sadeleştirme yönünde teklifler yapılmıştır (MEB, 1925). Bunların bir kısmı gerekçesi açıklanıp uygulamada çıkan sıkıntılar olduğu vurgulanırken bir kısmı gerekçesi açıklanmadan sadece teklif edilmiştir. Sadeleştirme veya açık hale getirme yönündeki tekliflerin uygulamada sıkıntılardan kaynaklandığı anlaşılıyorsa da milli bir devlet kurulmasıyla da ilgisi vardır. Neticede Osmanlı́nın son döneminde ortaya çıkan Türk milliyetçiliği fikri yeni Türkiye Cumhuriyeti'nin temel ideolojisi olarak benimsenmiştir. Milli devletin önemli bir unsuru olan dil ve dilde sadeleşme fikri gelişme sürecindedir (Koç, 2007: 11-24; Kerimoğlu, 2008: 103-117). Öte yandan çeşitli yerlerden gelen değişiklik tekliflerinde talebenin dindar yetiştirilmesine dair herhangi bir ifade bulunmaması laik eğitim anlayışına yönelme olarak görülebilir. Kişi egemenliğinden henüz çıkılıp Cumhuriyet yönetimine geçilirken bu anlayışa uygun olarak Maarif Vekâleti taşra teşkilatlarından talimatname tadili için görüş istemiştir. Bu tadilat tekliflerinden sonra yeni talimatname Illk Mektepler Talimatnamesi adıyla 1929'da çıkarılmıştır.

\section{Illk Mektepler Talimatnamesinin 1915 Mekatib-i İbtidaiye-i Umumiye Talimatnamesi ile Karşılaştırılması ve Değişiklik Tekliflerinin Talimatnameye Yansıması}

Talimatname 1929 yılında Maarif Vekâleti tarafından 61 sayfalık bir kitapçık olarak basılmıştır. Üç kısım ve ilavesiyle 169 maddeden oluşmuş, fihrist ve indeks yer almıştır ("ilk Mektepler Talimatnamesi", 1929: 1-61).

Birinci kısımda esaslar başlığı altında ilköğretimin amacı verilmiştir. Buna göre ilk tahsil yaşındaki çocukların bedence ve ruhça sağlam alışkanlıklar edinmesini sağlayacak bir çevrede en gerekli bilgi ve maharetleri kazanmaları ile milli cemiyete ve Türkiye Cumhuriyeti'ne ruhen ve bedenen faydalı olarak intibak etmelerinin sağlanmasıdır ("ilk Mektepler Talimatnamesi", 1929: 1). Çocuğun beden ve ruhça milli bir topluma uyum sağlamasının amaçlanması yeni kurulmuş olan milli devletin temellerini sağlamlaştırmakla ilgilidir. Eski talimatnamedeki dindarlık vurgusu yeni talimatnamede yer almamıştır. Eski talimatnamede açık olmayan Türk milliyetçiliği fikri ise 1929 'da açık ve net olarak ifade edilmiştir.

Kayıt muamelesi 3-11. maddeler olup yukarıda anlatılan tadilat tekliflerinin yansımasını burada görmek mümkündür (“ilk Mektepler Talimatnamesi”, 1929: 3-6). Hasta ve anormal çocukların kabul edilmemesi, okula başlama ve bitirme yaşının daha açık hale getirilmesi, kayıt süresinin derslerin başlamasından on beş gün önce başlayıp bir ay sonraya kadar sürmesi, hangi durumlarda çocuğun başka bir mektebe her zaman kayıt yapılacağı, kayıtların nasıl yapılacağının daha açık hale getirilmesi yukarıda anlatılan zaten istenen değişikliklerdir. Taşra 
teşkilatlarından bu yönde gelen teklifler kabul edilmiştir. İş ve tatil zamanları 12-20. maddelerdir (“ilk Mektepler Talimatnamesi”, 1929:6-9). Bu kısımdaki mektepler nüfusu 10.000 'den fazla olan yerlerde 40 , daha küçük şehirlerde 36 , köylerde 30 haftadan az açık olamaz hükmü yine çeşitli tadil tekliflerinin yansımasıdır. Ayrıca tatil ve ders zamanlarının belirlenmesinde köylerin durumlarının dikkate alınması, resmî tatil günlerine Cumhuriyet Bayramının, Millet Meclisi ve çocuk bayramının, mahalli kurtuluş bayramlarının ilavesi, Cumhuriyet ve çocuk bayramlarında resmî törenler düzenlenmesi, ders başlama saatlerinin en erken 8 en geç 9 olması bu konuda mahallin özelliklerinin dikkate alınması tadilat tekliflerindendir. Bu maddeleriyle eski talimatnameye göre daha açık ve anlaşılır haldedir.

Terbiye ve tedris başlığı altındaki terbiye alt başlığında 21-37. maddeler oldukça ayrıntılıdır (“ilk Mektepler Talimatnamesi”, 1929: 10-14). Talebenin birbirleriyle davranışları, düzen tertip, çalışkanlık, sebat, oyunlar, mektep binasının korunması, talebenin aynı tarzda kıyafeti, ağız bozukluğu, nezaket, terbiye, tutumlu olmak, toplumsal kurallara alıştırılması, terbiyede Türklük ve Türk vatanının temele alınması, milli duyguların güçlendirilmesi, bayramlarda inkılapların nimetlerinin anlatılması ile ilgili ayrıntılı hükümler getirmiştir. Bu hükümlerin bir kısmı yukarıda açıklanan tadilat tekliflerinde söz konusu olmuştur. Eski talimatnameyle karşılaştırıldığında çocuğun terbiyesinde daha hassas ve ayrıntılı hükümler getirilmiştir. Bu terbiyenin en önemli amacı milli devlete sahip çıkacak kuşaklar yetiştirilmesi olup bunun nasıl yetiştirileceği somutlaştırımıştır. Hâlbuki eski talimatnamede çocuğun terbiyesi ile ilgili maddeler bu kadar ayrıntılı değildir. Mesela çocuğun oyun oynamasına dair maddeler varsa da çocuğun ağız bozukluğu, nezaket, tutumlu olmasıyla ilgili ayrıntılı maddeleri yoktur. Ayrıca eski talimatname Osmanlı döneminde hazırlandığı ve bünyesinde farklı etnik kökenden insanları barındırdığı için doğal olarak açıkça Türk milliyetçiliği, milli devlet vurgusu yoktur. Tedris başlığı altında 38-52. maddelerde müfredat programları, irtibat cetvelleri ve tedris usullerine dair talimatnamelerin dikkate alınacağı belirtilmiştir ("ilk Mektepler Talimatnamesi", 1929: 14-19). Tedrisatın terbiyevi olması, sınıf tarzının uygulanması, talebenin zihni, hissi, iradi terbiyesine etkili olunması, Türkçe, tarih, coğrafya, yurt bilgisi derslerinde milliyet ve vatan terbiyesi, hesap, hendese derslerinde muhakeme kabiliyetinin geliştirilmesi, gibi ayrıntılı örneklerle derslerin terbiyevi amaçlarla ilişkilendirilmesi, doğa sevgisinin aşılanması, hissi terbiyede aşırılığa kaçılmaması, müfredat ve irtibat cetvellerindeki mevzuların mahallin şartlarına göre tedris edilmesi, mektep dışındaki içtimai müessese ve faaliyetlerin incelenmesi için geziler yapılması, talebenin bu konularda fikir sahibi olması, geziler hakkında ayrıntılı hükümler konulması, çocuğun derse ilgisinin sağlanması, ders kitaplarının ezberlettirilmesinden kaçınılması, tedrisatın uygulamaya dönük olmasına dair ayrıntılı maddeler yer almıştır. Bunların bir kısmı tadilat tekliflerinde var olan istekler olup yeni talimatnameye de girmiştir. Bu maddeler eski talimatnamedeki ilgili hükümlerle karşılaştırıldığında mesela 45. maddesinde zihni, hissi, iradi terbiye vurgusu bulunmakla birlikte bunun nasıl yapılacağına dair ayrıntılı hükümler yoktur. Hâlbuki yeni talimatnamenin 41. maddesinde bunun nasıl yapılacağı oldukça ayrıntılı olarak yer almıştır. Terbiye ve tedristeki maddelerde çocuğun toplum için eğitildiğini görmek mümkündür. Eski talimatnamede ise çocuğun öncelikle dindar yetiştirilmesi vurgusu vardır. Yine eski talimatnamede muallimin çocuğa dersin gayesini söylemesi söz konusu iken yeni talimatnamede böyle bir şey yoktur. Tadilat tekliflerinde bunun kaldırılması istenmiş, her ders 
için uygun olmadığı belirtilmişti. Ders vazifeleri 53-56. maddelerdir ("ilk Mektepler Talimatnamesi", 1929: 20-21). Musiki, jimnastik gibi derslerde evde vazife verilemeyeceği, verilen vazifelerin kontrolü, bazen talebenin birbirlerine kontrol ettirilmesi, çok tekrar eden hataların sınıfta tartışılması, şifahi vazifelerin verilmesi, vazifelerin çok verilmemesi, zararları gibi maddeler tadilat tekliflerinde de görülmüştür. Bu kısımda eski talimatnameyle farklar olmakla birlikte azdır.

Mükâfat ve mücazat başlığında 57-59. maddelerde mükâfat ve mücazatın talebenin iyi davranışlarını geliştirmek, kötüsünü izale etmek amacında olduğu, ilk mekteplerde maddi mükâfat ve mücazat bulunmadığı, çalışkan öğrenciye yılsonunda verilebilecek kitabın mükâfat değil okulun hediyesi olarak verilmesi, intizamsızlık, devamsızık, arkadaşlarıyla iyi geçinmeme gibi durumlarda sözlü ihtar, yazılı ihtar, ders mahiyetinde olmayan gezilerden men, iki günden altı güne kadar teneffüslerde oyunlardan men, muallimler önünde tevbih, başka bir mektebe nakil gibi cezalar belirlenmiş, bir kısmı yine tadilat tekliflerinde anlatılmıştı ("ilk Mektepler Talimatnamesi", 1929: 21-22). Arkadaşları önünde azarlanma faydalı görülmeyip çıkarılması gibi cezalandırmalar dışında eski talimatname ile kıyaslandığında büyük bir değişiklik yoktur. Ancak daha sade bir Türkçe ile ifade edilmiştir.

Imtihanlar başlığıyla 60-74. maddelerde beşinci sınıfları bitiren talebe bitirme imtihanına tabi tutulur, diğer sınıflarda ders yılında yoklamalarda verilen notlara göre sınıfı geçer veya kalır, her sınıftaki ders zümreleri, her dersin notlarının nasıl verileceği ayrıntılı açıklanmış, imtihanlarda mümeyyiz getirilmesi maarif idarelerinin lüzumlu görmesi durumu hariç kaldırılmış, mektebin bütün muallimlerinin imtihanlarda bulunması zorunlu hale getirilmiştir (“ilk Mektepler Talimatnamesi”, 1929: 22-28). Notların verilmesinde anlaşmazlık durumları, notların dereceleri, hususi mekteplerden gelenlerin ilk tahsil imtihanlarının diğer talebe ile birlikte yapılması ile ilgili ayrıntılı hükümler tadilat tekliflerinin yansımasıdır. Eski talimatnamedeki mümeyyizler ve başmuallimin not vermedeki etkisi ortadan kaldırılmıştır. Fakat İlk Tahsili Bitirme İmtihanının nasıl yapılacağı eski talimatnameye göre daha ayrıntılı olarak düzenlenmiştir.

Karneler, nakil tasdiknameleri, şahadetnameler başlığı altında 76-79. maddelerde eski talimatnameye göre çok dikkat çekici bir değişiklik yoktur ("ilk Mektepler Talimatnamesi", 1929: 28-29). Benzer şekilde vazifeler başlığı altında 80-100. maddeler başmuallimin vazifeleri ile ilgili olup idari görevlerinde büyük değişiklikler yoktur. Fakat ufak değişikliklerle daha açık hükümler getirilmiştir ("ilk Mektepler Talimatnamesi”, 1929: 30-34). Aynı şekilde açık ifadeleri muallimler başlığı altındaki 101-116. maddelerde de görmek mümkündür (“ilk Mektepler Talimatnamesi", 1929: 34-38). Derslerin verilmesi ile ilgili hükümler daha ayrıntılı düzenlenmiştir. Muallimler meclisi ve inzibat komisyonu 117-121. maddeler olup disiplin işlerinin yürütülmesi ile ilgilidir (“ilk Mektepler Talimatnamesi”, 1929: 38-39). Büyük değişiklikler yoktur. Kalem işleri 122-124. maddeler olup mektepte tutulacak defter ve kayıtlar ile nasıl tutulacağı hakkındadır, büyük değişiklikler yoktur (“ilk Mektepler Talimatnamesi”, 1929: 39-40). Bu kısımlarda eski talimatname ile arasında en önemli fark talimatın tümüne yansımış olan daha sade Türkçe ifadeler kullanılmış olmasıdır.

Mektepte içtimai faaliyetler 125. madde olup 12 fıkradan meydana gelmiştir ("ilk Mektepler Talimatnamesi”, 1929: 40-44). Okulun sosyal bir ortam olarak çocuğun eğitilmesine 
uygun bir yer haline getirilmesi için ayrıntılı faaliyetler yer almıştır. Her sınıfta talebelerden oluşan temizlik ve intizam gözcüleri, haysiyet divanı, koleksiyonculuk, tasarruf sandığı, hilali ahmer ve himaye-i etfale yardım, hayvanların himayesi gibi amaçlarla cemiyetler kurulması, başka vilayetler mektepleriyle mektuplaşma, duvar gazetesi, spor faaliyetleri, kız ve erkeklerin birbirleriyle nazik ve terbiye içinde davranmaları, fakir talebeye yardımın aleni olmaması, milli bayramlardan milli cemiyete bağlanma için faydalanılması, mektebin ebeveyn ile ilişkisinin sağlanması için faaliyetler düzenlenmesi gibi ayrıntılı hükümler vardır. Böyle bir kısım eski talimatnamede yoktur. Bu değişiklikler milli devletin milli eğitim politikasının sonucudur.

İkinci kısım bina ve müştemilat alt başlığında 126-140. maddelerde bina ve müştemilatın genişliği, güneşli ve sağlığa uygun, temiz olması ile ayrıntılı hükümler konulmuştur (“ilk Mektepler Talimatnamesi”, 1929: 45-48). Eski talimatnamede bina ve müştemilata ilişkin herhangi bir bölüm yok iken yeni talimatnamede ise buna önem verilmiştir. Eşya ve ders vasıtaları 141-150. maddelerdir (“ilk Mektepler Talimatnamesi”, 1929: 48-51). Sıraların şekli kullanılacak malzemeler, cumhurbaşkanının resminin bulunması, ders vasıtaları için ilk mekteplere mahsus ders aletleri rehberine müracaat edilmesi, duvarların süslenmesi, okulda bulunması zorunlu kitaplar gibi hükümler yer almıştır. Milli devlet anlayışının yansıması olmakla birlikte ders araç gereçlerinde eski talimatnameye göre büyük değişiklikler yoktur.

Üçüncü kısım mektepte sıhhi faaliyet ve hizmetler başlığında 151-164. maddelerde ayrıntılı hükümler getirilmiştir (“ilk Mektepler Talimatnamesi”, 1929: 52-55). Talebenin okuryazarken kitap ve kâğıda uzaklık mesafesi, sınıfların havalandırılması, sınıfların sıcaklık durumları, diş bakımı, fırçalanması, muayenesi, saç temizliği, bulaşıcı hastalık geçiren çocukların durumu, küçük bir eczane teşkil edilmesi, oyun sırasında yaralanmalar durumu, talebe arasında sıhhat derneği kurulması, kilo kontrolü, talebenin senede bir kere tabip muayenesinden geçirilmesi, kötü alışkanlıklar kazanmasının önlenmesi gibi ayrıntılı maddeler yapılmıştır. Tadilat isteklerinde sağlık ile ilgili teklifler daha ziyade kabul ve kayıt kısmında ifade edilmiş, mektebin sıhhi durumuna dair herhangi bir talep söz konusu olmamıştı. Öte yandan Vekâlet sağlık sorunlarının yaygın olması nedeniyle sadece mektebe kabul ve kayıt sırasında değil mektebin bir bütün olarak sağ Iığa uygun olması için ayrıntılı maddeler yapmıştır. Bu kısım da eski talimatnameye göre hayli farklıdır.

Illave başlığı altında 165-169. maddeler muallim ve dershane adedine göre sınıfların idaresi olup dershane ve muallim sayısı yeterli olan ve olmayan mekteplerdeki düzenlemelerdir ("ilk Mektepler Talimatnamesi", 1929: 56). Bunun için ayrı bir talimatname yapıldığı ifade edilmiştir. Eski talimatnamede ise bu durum dördüncü fasılda sınıfların taksimi başlığıyla ayrıntılı açıklanmıştır.

Talimatnamenin eski talimatname ile arasındaki en temel fark 1929 talimatnamesinin daha sade bir Türkçe ile milliyetçi devlet ideolojisine göre hazırlanmış olmasıdır. Eski talimatnamede ise milliyetçilik ön plana alınan dindarlık kavramının içerisine yerleştirilmiştir. Bunun dışında ülkenin sosyal ve ekonomik durumu talimatnamelerin hazırlanmasında ve tadil edilmesinde belirleyici olmuştur. Kişi egemenliğinden Cumhuriyet yönetimine geçilirken bu anlayışa uygun olarak Maarif Vekâleti taşra teşkilatlarından talimatname için görüş istemiştir. Talimatnameyi uygulayacak olan taşra maarif teşkilatlarındaki muallimler ve diğer görevliler ülkenin sosyal gerçeklerine merkezden daha vakıftırlar. Bu nedenle Vekâlet görüş istemekle 
kalmamış, bu görüşleri talimatnameye yansıtmıştır. Böylece usûl-ı cedîd ile başlayan Türk aydınlanması devam etmiştir denilebilir.

\section{Sonuç}

19. yüzyılda sosyal ve siyasal değişimler Avrupa'dan tüm dünyaya yayılmış, bu durum eğitim anlayışına yansımıştır. Çok uluslu imparatorluklar yıkılıp milli devletler ortaya çıkınca eğitim, özellikle temel eğitim milli devletin ideolojisine sahip çıkacak bireyler yetiştirmek düşüncesiyle devletin asli görevleri arasına girmiştir. Bu sırada dağılma sürecine giren Osmanlı Devleti'nde ise eğitime el atılırken asıl amaç devletin yıkılışını engellemekti. Bu yüzyılda eğitim alanında medrese dışında yeni bir eğitim anlayışı arayışı ve uygulamaları başlamış, buna usûl-ı cedîd denilmiştir. Usûl-ı cedîd yeni açılan mekteplerin ders araç gereç, kitap ve ders yöntemlerinde uygulanan yeniliklerdir. Illköğretimde de geliştirilen bu hareket ile sıbyan mekteplerinin yerini zamanla ibtidai denilen mektepler almıştır. ibtidai mekteplerin geliştirilmesi için bu yüzyılda çeşitli düzenlemeler yapılmıştır.

II. Meşrutiyet Döneminde çıkarılan 1913 tarihli Tedrisat-ı İbtidaiye Kanun-ı Muvakkatı'nda ise ilköğretim ayrı bir kanun ile düzenlenmiş, sistematik hale getirilmiştir. Kanunun ilgili maddesine göre 1915 yılında Mekatib-i ibtidaiye-i Umumiye Talimatnamesi çıkarılmıştır. Talimatname I. Dünya Savaşı sırasında çıkmış olup dönemin siyasi ve sosyal durumunu yansıtmaktadır. Talimatnamede dindar nesil yetiştirme amacı vurgulanmakla birlikte yeni ortaya çıkan Türkçülük fikri çok açık olmasa da yansımıştır. Ön planda olan dindarlık kavramının içine milliyetçilik kavramı yerleştirilmiştir. Bu yönüyle eski talimatname çok uluslu bir devletten milli devlete geçiş dönemi özelliğini yansıtmaktadır. Talimatnamenin 1923'teki baskısında saltanatın kaldırılması ve Cumhuriyetin ilanı nedeniyle bazı değişiklikler ve sadeleştirmeler yapılmış ve 1929 yılına kadar kullanılmıştır. Bu tarihe kadar milli devlete geçişte önemli inkılaplar yapılmış, milli devlet ideolojisi benimsenmiştir. Milli eğitim politikasının temeli olan Tevhid-i Tedrisat Kanunu çıkarılmıştır. Osmanlı'dan devr alınan mevcut talimatname yetersiz kalmıştır.

Maarif Vekâleti 1925 yılında taşra teşkilatlarına yazı göndererek mevcut talimatname üzerinde yapılması gereken tadilat hakkında görüş istemiştir. Cumhuriyeti ilan eden kadro bu uygulaması ile ideolojisine uygun davranmıştır. Şüphesiz taşra teşkilatları talimatnameyi uygulayacak olan kadrolar olup ülkenin sosyal durumuna vakıftırlar. Bu nedenle Vekâlet tarafından taşradan görüş istenirken milli eğitim sisteminin ülke gerçeklerine uygun bir şekilde düzenlenmesi amaçlanmıştır. Taşra teşkilatlarından çok sayıda hemen her madde ile ilgili tadilat teklifleri gelmiştir. Teklifler genellikle milli devlet ideolojisine uygun değişikliklerdir. Eski talimatnamede yer alan dindar nesil yetiştirilmesiyle ilgili herhangi bir teklif incelenen belgelerde yer almamıştır. Bu yönüyle Osmanlı'da gelişen usûl-ı cedid ile daha laik bir eğitim anlayışını benimsemiş kuşaklar yetiştiği söylenebilir. Taşra teşkilatlarıyla birlikte yapılan bu çalışmalar neticesinde 1929 'da yeni bir ilk mektepler talimatnamesi yayınlanmıştır. Taşra teşkilatlarından gelen değişiklik teklifleri Vekâlet tarafından önemsenmiş ve talepler doğrultusunda 1929 talimatnamesi hazırlanmıştır. Artık yeni talimatnamede açıkça Türk 
milliyetçiliği vurgusu var iken eski talimatnamedeki dindar nesil yetiştirme vurgusu yoktur. Taşra teşkilatlarının tekliflerinde olmayan Vekâletin kendi insiyatifiyle yeni maddeler de eklenmiştir. Özellikle tedris ve terbiye, mektepte içtimai faaliyetler, mektepte sıhhi faaliyet ve hizmetler başlıkları altındaki maddeler tekliflerde bulunmayan maddelerdir. Milli eğitim anlayışı bağlamında, milli duyguların geliştirilmesine, becerikli, donanımlı bir nesil yetiştirilmesine önem verildiği gibi sağlıklı ve güçlü olmasına önem verilmiş ve devlet politikası haline getirilmeye çalışılmıştır. Neticede taşradan gelen değişiklik taleplerini dikkate alarak illk Mektepler Talimatnamesini hazırlayan Maarif Vekâleti bu çalışmaları ile milli devletin milli eğitim politikasını oluşturmaya sadece teorik olarak değil pratik olarak ta katkıda bulunmuştur.

\section{Kaynakça}

Akyüz, Y. (1994). İlköğretimin yenileşme tarihinde bir adım: Nisan 1847 Talimatı. OTAM, Sayı 5, s. 2-47.

Akyüz, Y. (2006). Türkiye'de öğretmen yetiştirmenin 160. yılında Darülmuallimin'in ilk yıllarına toplu ve yeni bir bakış. OTAM, Sayı 20, s. 17-58.

Akyüz, Y. (2012). Türk eğitim tarihi M.Ö.1000-2012. Ankara: Pegem Akademi.

Alkan, M. Ö. (2011). Tanzimat'tan Cumhuriyet'e modernleşme sürecinde eğitim istatistikleri (1839-1924). Ankara: T.C. Başbakanlık Devlet İstatistik Enstitüsü.

Aytaç, K. (1992). Avrupa eğitim tarihi. İstanbul: Marmara Üniversitesi Illahiyat Fakültesi Vakfı. Binbaşığlu, C. (2005). Türk eğitim düşüncesi tarihi. Ankara: Anı.

Binbaşıoğlu, C. (2014). Başlangıçtan günümüze Türk eğitim tarihi. Ankara: Anı.

Çakmak, F. (2009). Cumhuriyet'in ilk yıllarında nüfusu kayıt altına almaya yönelik girişimler. Erişim (6 Şubat 2020): https://ataturkilkeleri.deu.edu.tr/wpcontent/uploads/2015/01/Cumhuriyetin-\%c4\%b0lk-Y\%c4\%b1llar\%c4\%b1ndaN\%c3\%bcfusu-Kay\%c4\%b1t-Alt\%c4\%b1na-Almaya-Y\%c3\%b6nelikGiri\%c5\%9fimler.pdf

Demirtaş, Z. (2007). Osmanlı'da sıbyan mektepleri ve ilköğretimin örgütlenmesi. Erişim (6 Şubat 2020): http://web.firat.edu.tr/sosyalbil/dergi/arsiv/cilt17/sayi1/173-183.pdf

Ergin, O. (1977), Türk maarif tarihi, cilt 1, 2. İstanbul: Eser.

Ergün, M. (2000). Medreseden mektebe Osmanlı eğitim sistemindeki değişme. Yeni Türkiye, Sayı 32, s. 735-753.

Hayta, N. (2018). Tarih araştırmalarına kaynak olarak tasvîr-i efkâr gazetesi (1278/18621286/1869). Ankara: Türk Tarih Kurumu.

İlk Mektepler Talimatnamesi. (1929). İstanbul: Devlet.

Illk Tedrisat Talimatnamesi. (1339/1342/1923). İstanbul: Matbaa-i Amire. 
Karaca, Ş. (2010). Şemsettin sami ve kadınlar. Erişim (6 Şubat 2020): http://www.sosyalarastirmalar.com/cilt3/sayi13kadinsayisipdf/karaca_sahika.pdf

Karasar, N. (1998). Bilimsel araştırma yöntemi (8. baskı). Ankara: Nobel.

Kurnaz, Ş. (1991). Cumhuriyet öncesinde Türk kadını (1839-1923). Ankara: Başbakanlık Aile Araştırma Kurumu Başkanlığı.

Koçer, H. A. (1992). Türkiye'de modern eğitimin doğuşu ve gelişimi. İstanbul: Milli Eğitim Bakanlığı.

MEB, Cumhurbaşkanlığı Devlet Arşivleri Başkanlığı Cumhuriyet Arşivi, Milli Eğitim Bakanlığı/180-9-0-0, Kutu 110, Gömlek 534, Sıra 1; Kutu 110, Gömlek 535, Sıra 1.

Mekatib-i İbtidaiye-i Umumiye Talimatnamesi. (1331/1915). İstanbul: Matbaa-i Amire.

Nurdoğan, A. M. (2005). Osmanlı modernleşme sürecinde ilköğretim (1869-1922). (Basılmamış doktora tezi). Marmara Üniversitesi, Türkiyat Araştırmaları Enstitüsü, İstanbul.

Öztürk, C. (1996). Atatürk devri öğretmen yetiştirme politikası. Ankara: Türk Tarih Kurumu.

Maarif Nezareti'nin Tarihçesi. (1316). Salname-i Nezaret-i Maarif-i Umumiye, 1316 Sene-i Hicriyesine Mahsus, Matbaa-i Amire, s. 17-37.

Temizyürek, F. (2014). Gaspıralı ismail bey'in cedit mektepleri üzerine. Erişim (6 Şubat 2020): http://isamveri.org/pdfdrg/D03371/2014_4/2014_4_TEMIZYUREKF.pdf

Tezcan, M. (1985). Eğitim sosyolojisi. Ankara: Eğitim Bilimleri Fakültesi.

Türkiye Büyük Millet Meclisi Zabıt Ceridesi. (1921). Cilt 8, İçtima Senesi I, 148. İçtima.

Türkiye Büyük Millet Meclisi Zabıt Ceridesi. (1925). Cilt 15, İçtima Senesi II, 73. İçtima.

Unat, F. R. (1964). Türkiye eğitim sisteminin gelişmesine tarihi bir bakış. Ankara: Milli Eğitim Bakanlığı.

Ünal, U., Birbudak, T. S. (2013). İstanbul darülmuallimîni (1848-1924). Ankara: Atatürk Araştırma Merkezi.

Yıldırım, A. ve Şimşek, H. (2003). Sosyal bilimlerde nitel araştırma yöntemleri. Ankara: Seçkin.

Yüksel, M. Ş. (2009). Timurlularda din-devlet ilişkisi. Ankara: Türk Tarih Kurumu. 